\title{
Banyuwangi: Kota Festival Menuju Destinasi Wisata Indonesia dan Dunia
}

\author{
Purwowibowo $^{1}$ \\ purwowibowo.unej@gmail.com
}

\begin{abstract}
Tourism has become a leading sectors of Banyuwangi Regency to realize the social welfare of the whole communities. This can be seen from the program that was launched by this district to become a major program and important tourist destination in Indonesia, not only for local tourists but also foreign tourists. In fact, the last 5 years the Banyuwangi Regency has made a program that is believed to be an effort to boost tourism activities on a massive scale. The program is a festival, which are a program designed and implemented by all local government officials and supported by the all communities. In 2019, the number of festivals held was 99 activities, one of which is the phenomenal festival that is the 'Gandrung Sewu Festival'. With so many festivals, Banyuwangi and then that city was called and becomes the 'City of Festivals'.
\end{abstract}

Keywords: Banyuwangi, Tourism, Social Welfare, Festival City, Gandrung Sewu

\begin{abstract}
Abstrak
Kepariwisataan telah menjadi bidang unggulan Kabupaten Banyuwangi untuk mewujudkan kesejahteraan sosial seluruh masyarakatnya. Hal ini terlihat dari program yang dicanangkan kabupaten ini menjadi destinasi wisata utama dan penting di Indonesia, tidak hanya wisatawan lokal tetapi juga wisatawan mancanegara. Bahkan, 5 tahun terakhir ini Kabupaten Banyuwangi membuat program yang diyakini sebagai upaya yang dapat mendongkrak kegiatan pariwisata secara 'massive'. Program itu adalah festival, yakni suatu program yang dirancang dan diimplementasikan oleh seluruh aparat pemerintah daerah dan didukung oleh masyarakat. Tahun 2019, jumlah festival yang diselenggarakan sebanyak 99 kegiatan, salah satunya yakni festival yang fenomenal adalah 'festival gandrung sewu'. Dengan banyaknya festival tersebut Banyuwangi disebut dan menjadi 'Kota Festival'.
\end{abstract}

Kata Kunci: Banyuwangi, Pariwisata, Kesejahteraan Masyarakat, Kota Festival, Gandrung Sewu

1 Dosen Jurusan Ilmu Kesejahteraan Sosial, FISIP, Universitas Jember 


\section{Pendahuluan}

Dua tahun terakhir ini, kota Banyuwangi menjadi sangat terkenal, bukan hanya di Indonesia, tetapi juga dunia. Hal ini tentu terkait dengan berbagai festival yang diselenggarakan di kota wisata ini. Pada tahun 2012 sampai 2017, penyelenggaraan festival hanya 12 sampai 20 even festival dalam setahun. Sedangkan, tahun 2018 melonjak menjadi 75 festival dan tahun 2019 bertambah menjadi 99 festival. Di bulan Oktober tahun 2019 ini, diselenggarakan festival fenomenal yakni 'Tari Gandrung Sewu', suatu tarian tradisional 'kolosal' yang dibawakan oleh 1000 penari wanita (Cahyadi, R., 2019).

Suatu penyelenggaraan festival yang melibatkan banyak orang dan mampu mendatangkan banyak wisatawan lokal dan mancanegara ke kota Banyuwangi. Ketika naik pesawat ke berbagai tujuan di Indonesia, maka akan ditemukan brosur tentang kegiatan terkait dengan promosi daya tarik wisata di Banyuwangi, yang sangat luar biasa, yakni salah satunya 'festival gandrung sewu'. Saat ini, Kota wisata yang menjadi destinasi unggulan baru di wilayah Jawa Timur bagian timur ini disorot banyak pihak terkait dengan upaya pemerintah daerah dan seluruh masyarakatnya untuk menjadikan kota Banyuwangi menjadi destinasi penting di Indonesia (Darmawan, E. W. dan Sanawiri, B., 2018).

Kota Banyuwangi, di tahun 2019 ini telah menjadi destinasi unggulan. Kota ini melakukan 'city branding' dan 'city image' (Jannah, 2014), sehingga mampu mensejajarkan dengan destinasi yang telah lama dikenal dunia, yakni Bali dan Yogyakarta. Saat ini, Banyuwangi menjadi pilihan berwisata bagi wisatawan lokal dan mancanegara. Kalau sebelumnya, wisatawan lokal dan mancanegara akan mengunjungi dua tempat wisata legendaris itu, sekarang Kota Banyuwangi telah menjadi tempat kunjungan pilihan yang menjanjikan. Dulu, kota Banyuwangi hanya sekedar tempat singgah atau sekedar numpang lewat, dari wisatawan yang berkunjung ke Bali maupun ke Yogyakarta, maka sekarang ini telah menjadi destinasi pilihan utama.

Pada umumnya, wisatawan sudah berulangkali datang ke Indonesia, terutama yang berwisata ke Bali dan Yogyakarta (Yuniati, N., 2018). Dengan berulang kali datang, sehingga mereka sudah merasa jenuh dengan destinasi dari dua tempat tersebut. Kota Banyuwangi, hadir sebagai pilihan manakala wisatawan belum menemukan tempat wisata budaya, alam-lingkungan yang baru dan berbeda dengan kedua destinasi tersebut. Banyuwangi menawarkan pesona berwisata yang tidak kalah menariknya dan sulit dilupakan bagi wisatawannya tentang budaya dan lingkungan yang menjadi tempat wisatanya karena sangat menarik dan atraktif. Banyuwangi sangat penting untuk dikunjungi oleh para wisatawan, baik yang lokal maupun mancanegara.

Perkembangan kota Banyuwangi menjadi destinasi penting bagi wisatawan lokal dan mancanegara tidak terlepas dari upaya pemerintah daerah dan seluruh masyarakatnya melakukan berbagai langkah promosi. Diantaranya adalah melakukan branding bahwa 'Banyuwangi Kota Wisata'. Di mulai tahun 2000-an sampai tahun 2019 ini, Kota Banyuwangi menjadi destinasi wisata nasional dan internasional, karena tempat ini telah menyandang beberapa julukan, di antaranya: 'The Sunrise of Java', 'Bumi Blambangan', 'Kota Osing', 'Kota Santet', 'Kota Gandrung', 'Kota Banteng., 'Kota 
Pisang', dan 'Kota Festival'. Dengan program kota festival diharapkan wisatawan lokal dan mancanegara berkunjung ke Banyuwangi bertambah banyak.

\section{Tinjauan Pustaka}

\section{Pengembangan Kepariwisataan}

Bidang

Pengembangan bidang pariwisata ditujukan untuk meningkatkan kualitas hidup dan kesejahteraan seluruh masyarakat sehingga meningkat taraf kehidupannya. Paling tidak, secara ekonomi, kegiatan kepariwisataan mempunyai dampak terhadap peningkatan ekonomi masyarakat lokal (Aref, 2009). Bidang pariwisata, dapat memberikan kontribusi dan akselerasi peningkatan kegiatan ekonomi serta mampu menjadi 'multiplier effect' bidang kehidupan sosial seluruh masyarakat, terutama bagi seluruh masyarakat di Singapura (Khan, 1990).

Guna dapat mewujudkan bidang pariwisata yang mampu menggerakkan kehidupan masyarakat, keberhasilannya ditentukan oleh beberapa faktor, diantaranya: (a) promosi dan layanan; (b) lingkungan dan pribadi; (c) faktor psikologi; (d) faktor harga; (e) faktor nilai; dan (f) faktor keandalan ( Pranata, 2013). Sedangkan faktor lain yang berperan dalam menentukan wisatawan berkunjung ke objek wisata adalah, (a) destinasi yang mempunyai keunggulan kompetitif dan komparatif; (b) destinasi yang mempunyai keunggulan atraktif; (c) atau mempunyai keunggulan keduanya (Vengesayi, 2003). Selain itu, potensi wisatawan sebagai pengguna atau penikmat destinasi wisata sangat penting. Oleh karena itu, destinasi wisata perlu dikemas, di 'branding', dan dimasyarakatkan dengan berbagai usaha promosi.
Menurut Widyastuti (2010), pengembangan pariwisata tujuannya adalah untuk pelestarian lingkungan, bukan hanya lingkungan alami, lingkungan buatan, tetapi juga lingkungan sosial-budaya. Dengan lingkungan yang lestari maka beberapa bidang terkait juga tumbuh dan berkembang. Misalnya, bidang ekonomi bagi masyarakat desa dan kota. Hal ini terkait dengan tumbuh dan berdirinya hotel, restoran-kuliner, industri rumahan, perluasan pasar produk lokal, terserapnya tenaga kerja produktif, dan masih banyak lagi yang lainnya.

\section{Pengembangan Prasarana dan Sarana Wisata}

Prasarana adalah kelengkapan yang diperlukan sebelum sarana wisata dapat dikembangkan. Oleh karena itu, strategi pengembangan prasarana wisata menjadi sangat penting dalam kegiatan kepariwisataan (Primandary, 2013). Bisa berupa sumber daya alam dan sumber daya buatan dan mutlak dibutuhkan oleh wisatawan lokal maupun mancanegara di dalam perjalanannya menuju daerah tempat tujuan wisata. Contohnya adalah: jalan, listrik, air, telekomunikasi (sarana internet), terminal, jembatan, layanan perbankan, layanan kesehatan dan lain sebagainya.

Tugas pemerintah daerah menjadi sangat penting karena tempat wisata yang dikembangkan merupakan tanggung jawabnya. Pariwasata juga mampu meningkatkan Pendapatan Asli Daerah (Nurhadi, 2014). Namun demikian, pariwisata terkadang tidak secara langsung meningkatkan pendapatan asli daerah (PAD), tetapi kegiatan kepariwisataan mempunyai dampak ganda dan bahkan mempunyai dampak luas terhadap perekonomian dan kehidupan masyarakat. 
Sedangkan, sarana wisata merupakan kelengkapan pendukung yang tidak kalah pentingnya dan sangat diperlukan di dalam memberikan layanan bagi wisatawan dalam menikmati kunjungan wisatanya. Sarana wisata yang harus disediakan di dalam daerah tujuan wisata, seperti misalnya: hotel, biro perjalanan, alat transportasi, rumah makan atau kuliner, dan sebagainya.

Dengan semakin lengkap, prasarana dan sarana di daerah tempat tujuan wisata akan mampu meningkatkan daya tarik dari objek wisata yang dikembangkan. Berkembang dan hidupnya industri kepariwisataan sangat ditentukan oleh kedatangan atau kunjungan wisatawan, yang tentu saja didukung dengan prasarana dan sarana yang memadai dan diperlukan.

\section{Pengembangan dan Promosi Wisata}

Destinasi yang bagus dan menarik merupakan potensi penting dalam industri pariwisata. Namun, di era sekarang ini, belum cukup. Destinasi atau daya tarik wisata harus dikembangkan dan dipromosikan. Salah satu kegiatan promosi adalah menggunakan media sosial (Umami, 2015).

Strategi ini terkait dengan penggunaan media sosial bagi masyarakat luas. Dalam promosi ini, seluruh kegiatannya adalah semua program yang dimaksudkan untuk mempertemukan permintaan dan penawaran, antara para wisatawan untuk mendapatkan kepuasan dan penyelenggara kepariwisataan yang mendapat keuntungan maksimal dengan risiko yang rendah melalui media sosial. Hal ini termasuk menyelenggarakan promosi, menilai, menstandarisasi, mengangkut, sampai kepada memperoleh informasi pasar yang sebanyak mungkin dari media sosial.

Promosi wisata berarti juga memasarkan objek dan daya tarik wisata. Oleh karena itu, sasaran promosinya adalah objek dan daya tarik wisata yang dijadikan destinasi wisata yang dipasarkan. Selain itu, juga prasarana dan sarana, layanan yang diberikan, dan semua yang terkait dengan penyelenggaraan pariwisata. Dengan mengetahui secara detail destinasi wisata serta prasarana dan sarana melalui sosial, maka keputusan wisatawan untuk mengunjungi jauh lebih kuat sehingga dapat menambah kedatangan wisatawan lokal dan mancanegara.

\section{BANYUWANGI DESTINASI WISATA NUSANTARA DAN DUNIA}

\section{Banyuwangi Kota Budaya}

Perjalanan dan perkembangan kota Banyuwangi tidak bisa dilepaskan dari sejarah panjang Kerajaan Blambangan (Zulfahri, M. H., et al., 2015). Pada pertengahan abad ke-17, kota Banyuwangi merupakan bagian dari pemerintahan Kerajaan Hindu Blambangan. Pada waktu itu, kerajaan ini dipimpin oleh seorang Pangeran yang bernama Tawang Alun. Banyuwangi merupakan wilayah penting dan banyak disebut dalam sejarah Indonesia.

Pada masa kolonial Belanda, pemerintah yang secara administratif diselenggarakan oleh VOC (Vereenidge Oostandische Compagnie), menganggap Blambangan atau Banyuwangi sebagai wilayah kekuasan dari pemerintahannya. Hal ini dilandasi oleh penyerahan kekuasaan Jawa Bagian Timur dan juga wilayah Blambangan dari Pakubuwono II kepada VOC. Menurut catatan sejarah, 
Kerajaan Mataram belum pernah mampu menguasai daerah Blambangan, yang merupakan 'Kerajaan Hindu' tersisa kala itu, di pulau Jawa.

Walaupun sudah mendapat mandat untuk menguasai Blambangan, tetapi VOC tidak pernah benar-benar mampu menancapkan kekuasaannya di wilayah ini. Kemudian, sampai pada akhir abad ke-17, tatkala pemerintah Inggris menjalin hubungan dagang dengan Blambangan maka memberikan bekas hubungan Inggris dan Blambangan yakni sutau daerah yang sekarang dikenal sebagai 'kompleks Inggrisan'. Masyarakat sampai sekarang mengenalnya dengan sebutan bekas kantor dagang Inggris di bumi Blambangan Banyuwangi.

VOC tidak tinggal diam setelah penyerahan kekuasaan tersebut dan kemudian segera bergerak untuk mengamankan kekuasaanya atas Blambangan akhir abad ke-18. Tindakan ini menyulut perang besar selama lima tahun (1767-1772) antara VOC dan Kerajaan Blambangan. Dalam berbagai peperangan, ada salah satu perang besar yang disebut 'Puputan Bayu', merupakan upaya terakhir Kerajaan Blambangan dalam mempertahankan kerajaannya. Namun, VOC yang memenangkan sehingga pertempuran itu menewaskan banyak orang yang dibuang ke sungai. Tatkala, sungainya yang banyak mayatnya bukan berbau busuk melainkan berbau 'wangi', kemudian wilayah Blambangan disebut 'Banyuwangi'.

Sebagaimana biasanya, VOC mengangkat bupati sebagai kepala wilayah Banyuwangi dan untuk pertama kali, pejabatnya adalah $\mathrm{R}$. Wiroguno I (Mas Alit). Namun demikian, perlawanan rakyat masih terus berlangsung secara sporadis. Hal ini, ditandai tidak adanya pabrik gula di wilayah Banyuwangi. Baru 5 tahun terakhir ini Banyuwangi mempunyai pabrik gula, sedangkan di wilayah Besuki setiap kabupaten mempunyai banyak pabrik gula.

Nama Banyuwangi kemudian dikuatkan dengan sebuah fiksi atau legenda tentang sejarah 'Putri Sri Tanjung' (Hutomo, 1996). Dalam kisah tersebut yang dibunuh oleh suaminya karena suaminya ragu atas janin yang dikandungnya. Si suami merasa bahwa janinnya bukan keturunannya melainkan hasil selingkuh istri.

Dalam cerita disebutkan manakala si istri dibunuh maka mayat dan janinnya dimohon untuk dihanyutkan ke sungai. $\mathrm{Si}$ istri berpesan, manakala bau air sungai atas mayat yang dihanyutkan dari mayat dirinya dan anaknya busuk - air sungai berbau busuk, dia berselingkuh. Namun, bisa air sungai, mayat diri dan anaknya harum, maka dia tidak selingkuh. Di akhir cerita, bahwa setelah pembunuhan 'Sri Tanjung dan Janinnya', ternyata sungainya harum atau wangi, kemudian wilayah itu dinamakan 'Banyuwangi'.

Perjalanan sejarah Banyuwangi juga tidak bisa dilepaskan dengan 'Pangeran Minak Djinggo' (Anoegrajekti, 2014). Dia adalah seorang Adipati Blambangan yang melakukan perlawanan terhadap kerajaan Mahapahit. Perlawanannya dapat dikalahkan oleh utusan Majapahit yang bernama Damarwulan. Kisah ini juga banyak diceritakan dalam sejarah. Penting untuk diketahui, bahwa Minak Djinggo, dirupakan dengan pemuda jelek. Hal ini terkait dengan asal-usul Minak Djinggo, yang merupakan anak dari Raja Wirabumi dari istri selirnya. Sesungguhnya, Minak Djinggo pemuda tampan, karena memberontak dan dari istri selir sehingga digambarkan pemuda yang tidak tampan. 
Dengan sejarah panjang kota Banyuwangi, maka berbagai destinasi wisata berdasarkan budaya banyak ditemukan. Bahkan, budaya 'Osing' yang merupakan ciri khas masyarakat Banyuwangi sampai sekarang dipertahankan dan dilestarikan untuk dijadikan daya tarik wisata di wilayah ini melalui Sastra Lisan Berbasis Industri Kreatif (Anoegrajekti, 2018). Berbagai kegiatan budaya seperti misalnya: 'Gandrung Sewu', 'Upacara Kebo-kebo-an', dan berbagai kegiatan budaya $O \operatorname{sing}$ lainya menjadi daya tarik wisatawan lokal dan mancanegara.

\section{Revitalisasi Destinasi Wisata Budaya dan Keindahan Alam}

Banyuwangi memiliki ratusan destinasi dan daya tarik wisata. Diantaranya, keindahan alam lingkungan sampai kekayaan budaya masyarakat setempat. Destinasi tersebut mulai dari: 'Ijen dengan BlueFire-nya' (Wirakusumah, 2019), 'Pantai Pulau Merah', 'Pantai Watu Dodol', 'Air Terjun Kalibendo', dan 'Taman Nasional Baluran' dan banyak lagi destinasi berdasarkan kondisi alam lingkungan.

Semuanya menyuguhkan panorama alam lingkungan yang sungguh mempesona bagi wisatawan lokal dan mancanegara. Sedangkan kekayaan sosial-budaya masyarakat yang masih terjaga secara turun temurun dan menjadi daya tarik wisata diantaranya adalah desa budaya yang sangat terkenal, yakni 'Desa Kemiren'. Desa ini menjadi tempat masyarakat Osing menjalankan tradisi budayanya, misalnya tari 'gandrung' sebagai wisata unggulan. Bahkan, tari gandrung tahun 2019 dilaksanakan secara kolosal untuk dapat menarik para wisatawan ke Kabupaten Banyuwangi.

Kemudian, berbagai peninggalan dan warisan purbakala dari para leluhur orang Banyuwangi, dijadikan objek wisata budaya. Wisata ini merupakan warisan nenek moyang pendahulu masyarakat Banyuwangi, yang jumlahnya cukup banyak. Seperti misalnya, situs peninggalan purbakala untuk wisata religi. Contohnya, makam Datuk Malik Ibrahim, Taman Perdamaian Dunia Watu Gedhek, Candi Alas Purwo, Klenteng Hoo Tong Bio, serta Pura Luhur Giri Saloka, dan lain sebagainya. Kekayaan ini dapat menambah destinasi wisata yang ada di Banyuwangi. Semua itu dijadikan objek dan daya tarik wisata terkait dengan wisata edukasi (Kinant, 2017).

Guna meningkatkan kunjungan wisatawan lokal dan mancanegara dari berbagai destinasi wisata budaya dan alam-lingkungan tersebut diperlukan usaha dari pemerintah dan seluruh masyarakat. Semua destinasi yang jumlahnya sangat banyak itu baru merupakan potensi potensial. Agar dapat dikunjungi oleh wisatawan dan menjadi daya tarik wisata, semua unsur mulai dari pemerintah kabupaten sampai tingkat desa harus bersamasama mem-'branding' dan kemudian mempromosikan atau memasarkannya.

Oleh karena itu, untuk dapat menarik wisatawan yang belum pernah berkunjung ke Banyuwangi, destinasi wisata tersebut perlu dipasarkan atau dipromosikan. Pemasaran destinasi wisata yang dilakukan pemerintah Banyuwangi bersama masyarakat dan telah mendatangkan banyak wisatawan dan menjadi fenomenal adalah kegiatan festival. Dibandingkan dengan wilayah lain, kegiatan festival di Banyuwangi jumlah sangat banyak, melibatkan semua aparat pemerintahan mulai dari kabupaten sampai desa serta melibatkan semua lapisan masyarakat. 


\section{Banyuwangi Kota Festival}

Pengembangan

potensi pariwisata di Banyuwangi yang luar biasa dibandingkan tempat lain menjadikan daerah ini menjadi tujuan wisata utama ketiga setelah Bali dan Yogyakarta. Sekarang ini, wisatawan lokal dan mancanegara banyak berwisata ke objek-objek wisata yang ada di wilayah ini. Hal ini tentu terkait dengan semua potensi tersebut dipasarkan atau dipromosikan.

Tujuan promosi wisata adalah berbagai objek dan daya tarik wisata dapat dikenal para wisatawan, baik domestik maupun mancanegara. Hal inlah yang senantiasa diedukasi pemerintah daerah Banyuwangi kepada seluruh jajaran aparat daerah mulai dari pemerintah kabupaten, kecamatan, sampai pemerintah desa (Irawan, 2015). Semua satuan pemerintah baik yang langsung berhubungan dengan pariwisata atau tidak langsung dalam Satuan Kerja Perangkat Daerah (SKPD) haruslah mempunyai mindset promo wisata di seluruh wilayah Banyuwangi.
Dengan merubah pola pikir atau mindset (Soekarsono, 2019), seluruh masyarakat, maka sekarang ini kota Banyuwangi menjadi destinasi wisata unggulan Indonesia dan Dunia. Wisatawan dapat menikmati objek dan daya tarik wisata di kota ini, sehingga banyak sekali menarik dan datang wisatawan lokal dan mancanegara. Wisatawan yang datang berkunjung dapat menikmati objek, daya tarik, dan destinasi wisata yang telah dikembangkan.

Usaha yang paling fenomenal (Cahyadi, R., 2019), adalah menyelenggarakan kegiatan festival. Festival oleh pemerintah daerah Banyuwangi dianggap sebagai promosi destinasi wisata yang paling efektif dan efisien karena mampu mendatangkan secara langsung wisatawn lokal dan mancanegara. Hal ini tampak dari perkembangan penyelenggaraan festival di Banyuwangi. Data di bawah ini menunjukkan Banyuwangi serius dalam mewujudkan kota festival untuk menarik wisatawannya datang dan menikmati objek dan daya tarik wisatanya.

Tabel 1 Penyelenggaraan Festival

\begin{tabular}{cc}
\hline Tahun & Jumlah Kegiatan Festival \\
\hline $2012-2017$ & $12-30$ \\
\hline 2018 & 75 \\
\hline 2019 & 99 \\
\hline
\end{tabular}

Sumber: Diolah Dari BPS dan Berbagai Sumber 2019

Dari tabel di atas menunjukkan bahwa Pemerintah Banyuwangi serius dan berkomitmen untuk menyelenggarakan kegiatan festival bersama seluruh masyarakat. Penyelenggaran festival sebanyak itu, tentu memerlukan dukungan pembiayaan yang tidak sedikit dan tenaga penyelenggara yang melibatkan berbagai unsur SKPD serta tokoh masyarakat. Tidak kalah pentingnya adalah masyarakat di Banyuwangi secara keseluruhan 'guyub' dan antusias mendukung serta berpartisipasi di dalam kegiatan festival.

Tahun 2019 merupakan rekor baru penyelenggaraan festival karena dalam setahun pemerintah kabupaten Banyuwangi menyelenggarakan 99 
kegiatan festival. Belum ada di kabupaten lain di Indonesia bahkan kota-kota lain di seluruh dunia yang mempunyai kegiatan festival sebanyak itu. Kalau dilihat dari jenis festival yang diselenggarakan pemerintah
Banyuwangi, tampak bahwa kegiatan festival dikaitkan dengan olah raga, musik, kuliner, dan kegiatan budaya serta religi.

Tabel 2. Jenis Festival

\begin{tabular}{|c|c|}
\hline Jenis Festival & Jumlah Kegiatan \\
\hline Sport & 28 \\
\hline Musik & 17 \\
\hline Kuliner & 16 \\
\hline Religi dan Budaya & 30 \\
\hline Milenial / Digital & 8 \\
\hline Jumlah & $\mathbf{9 9}$ \\
\hline
\end{tabular}

Sumber: Dinas Kebudayaan dan Pariwisata Banyuwangi 2019

Dari kegiatan festival seperti tabel di atas tampak bahwa kegiatan festival terkait dengan olah raga, musik, kuliner, religi dan budaya, serta milenial atau digital. Kegiatan festival berusaha mengakomodasi semua potensi wisata yang ada dan sedang dikembangkan serta melibatkan semua unsur masyarakat. Olah raga dan musik, tentu kawula muda banyak terlibat dalam kegiatan tersebut, sedangkan religi dan budaya tentu melibatkan tokoh masyarakat serta masyarakat pencinta budaya. Selain itu, festival di Banyuwangi juga berwawasan luas dan berorientasi dalam menghadapi perkembangan jaman, yakni menyelenggarakan festival milenial berbasis digital.

Dengan seluruh kegiatan festival yang diselenggarakan pemerintah Banyuwangi dengan melibatkan semua unsur SKPD serta masyarakat secara keseluhan, ternyata telah berdampak signifikan terhadap kedatangan wisatawan lokal dan mancanegara ke Banyuwangi. Hal tersebut dapat dilihat dari kedatangan wisatawan lokal dan mancanegara dalam 6 (enam) tahun terakhir di Banyuwangi seperti tabel berikut:

\section{Tabel 3. Kedatangan Wisatawan di Banyuwangi}

$\begin{array}{llllcc}\text { Tahun } & \text { Domestik } & \text { Mancanegara } & \text { Tahun } & \text { Domestik } & \text { Mancanegara } \\ 2012 & 660.832 & 8.690 & 2016 & 2.700 .000 & 75.000 \\ 2013 & 901.759 & 14.021 & 2017 & 4.600 .000 & 92.000 \\ 2014 & 1.500 .735 & 22.689 & 2018 & 5.000 .000 & 100.000\end{array}$

Sumber: Diolah dari, BPS, Banyuwangi 2018 dan berbagai sumber.

Dengan demikian jelas bahwa kegiatan festival mempunyai dampak signifikan terhadap kedatangan wisata, baik lokal maupun mancanegara. Dengan datangnya wisatawan telah menggiatkan perekonomian seluruh masyarakat Banyuwangi. Seorang wisatawan yang datang akan mempunyai dampak berganda terhadap kegiatan pada masyarakat, apalagi 
wisatawan lokal yang datang jumlahnya jutaan dan wisatawan mancanegara jumlahnya ribuan, sudah dapat dipastikan kegiatan perekonomian berkembang serta mendapatkan manfaat dari kedatangan wisatawan tersebut.

Selain itu, datangnya wisatawan ke Banyuwangi telah diikuti dengan tumbuhnya jumlah hotel yang terus bertambah, jumlah tenaga kerja terserap, jumlah restoran atau penyedia kuliner, petani, peternak, kegiatan ekonomi produktif, dapat tumbuh dan berkembang dengan kedatangan wisatawan. Kedatangan para wisatawan yang terus bertambah menjadikan Banyuwangi dikenal luas seluruh dunia dan sekarang ini menjadi destinasi wisata unggulan di Indonesia dan Dunia.

\section{Kesimpulan}

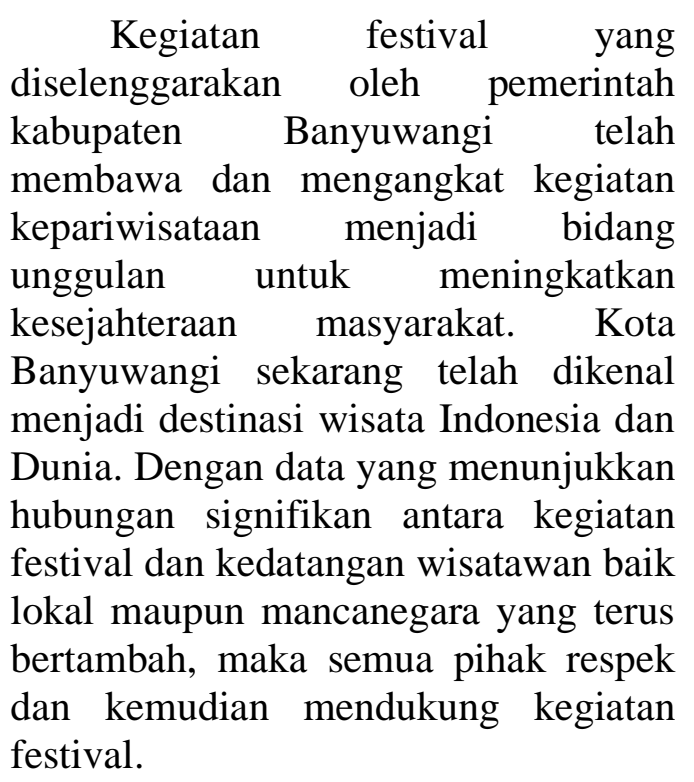

\section{Daftar Pustaka}

Anoegrajekti, N. (2014). Janger Banyuwangi dan Minakjinggo. Revitalisasi Budaya. Literasi. Vol 4. No. 1.

Anoegrajekti, N. dan Macaryus S. (2018). Sastra Lisan Berbasis
Industri Kreatif: Ruang Penyimpanan, Pengembangan, dan Identitas. Jurnal Atavisme. Vol 21 (1).

Aref, F. (2009) Community Perceptions Toward Economic and Environmental Impacts of Tourism on Local Communities. Journal of Asian Social Science, Vol. 5 No, 7 .

Cahyadi, R. (2019). Kearifan Lokal Sewu Gandrung Banyuwangi Sebagai Penunjang Literasi Budaya. Prosiding SENASBASA (Seminar Nasional Bahasa dan Sastra) Edisi 1 Tahun 2019 Halaman 59-66 E-ISSN 2599-0519. http://researchreport.umm.ac.id/index.php/SENAS BASA/article/view/2588/2530

Hutomo, S. H. dan Yonohudiyono, E. (1996) Asal Usul Banyuwangi. Gramedia. Jakarta.

Jannah, B. et al. (2014). Pengaruh City Branding Dan City Image Terhadap Keputusan Berkunjung Wisatawan Ke Banyuwangi. Jurnal Administrasi Bisnis (JAB). Vol. 17 No. 1 Desember 2014. http://administrasibisnis.studentjour nal.ub.ac.id/index.php/jab/article/vie $\mathrm{w} / 679 / 878$

Khan, H. et al. (1990) Tourism multiplier effects on Singapore. Annals of Tourism Research. Vol 17 Issue 3, p 408-418.

Kinant, L. A. B. et al. (2017). Uapaya Penyelamatan Benda Purbakala Sebagai Wisata Edukasi. Prosiding Seminar Nasional. SNAPER - EBIS. 2017

$\begin{array}{lr}\text { Kusuma, B. M. } & \text { A. } \\ \text { PEMBANGUNAN } & \\ \text { TERINTEGRASI } & \text { DALAM } \\ \text { MEWUJUDKAN } & \text { KOTA } \\ \text { PARIWISATA } & \text { BERTARAF } \\ \text { INTERNASIONAL: } & \text { STUDI } \\ \text { KASUS DI } \quad \text { KABUPATEN }\end{array}$


BANYUWANGI

JAWA

TIMUR. JKMP (ISSN. 2338-445X),

Vol. 2, No. 2,

http://ojs.umsida.ac.id/index.php/jk $\mathrm{mp} /$ article/view/433/375.

Nurhadi, F. D. C. et al. (2014). Strategi Pengembangan Pariwisata Oleh Pemerintah Daerah Terhadap PAD. Jurnal Administrasi Publik (JAP). Vol 2 No. 2.

Pranata, N., M dan Rahanatha, G. B. (2013) Faktor-faktor yang mempengaruhi Keputusan Wisatawan Domestik Berkunjung ke Bali Safari dan Marine Park Gianyar, Bali. Jurnal Manajemen. Vo 2 No 8.

Primandary, S. R. et al. (2013). Analisis Strategi Pengembangan Pariwisata Daerah. Jurnal Administrasi Publik (JAP). Vol. 1 No. 4. P 135-143.

$\begin{array}{llr}\text { Soekarsono, R. (2019) } & \text { Merubah } \\ \text { Mindset } & \text { ASN } & \text { Menjadi } \\ \text { Disruptive } & \text { Mindset } & \text { Sebagai } \\ \text { Faktor Penentu } & \text { Suksesnya } \\ \text { Implementasi Industri } & 4.0 \text { di } \\ \text { Indonesia. .Prosiding } & \text { Seminar } \\ \text { STIAMI. Vol 6. No.1. }\end{array}$

Umami, Z. (2015) Social Strategi Pada Media Sosial Untuk Promosi Pariwisata Daerah Istimewa Yogyakarta. Jurnal Interaksi. Vol 4 No 2.

Vengesayi, S. (2003). A Conceptual Model of Tourism Destination Competitiveness and Attractiveness. ANZMAC. Conference Proceeding Adelaide, 1 -3 December.

Widyastuti, A. R. (2010). Pengembangan Pariwisata Berorientasi Pada Kelestarian Lingkungan. Jurnal Ekosains. Vol 2, No. 3. Oktober 2010.

Wirakusumah, A. Dj. et al. (2019). Geotourism of Banyuputih Catchment Area, Mount Ijen, East Java, Indonesia. Journal of Physics Conference Series. 1363.

Zulfahri, M. H. et al. (2015). Kilas Balik Sejarah Budaya Semenanjung Blambangan, Banyuwangi, Jawa Timur. Kalpataru. Majalah Arkeologi. Vol. 24, No. 2 November 2015. 159-170. http://jurnalarkeologi.kemdikbud.go. id/index.php/kalpataru/article/view/4 $\underline{2}$ 